\title{
Improving Scientific Creativity and Scientific Attitude of Students through Creative Responsibility Based Learning on Energy-Work Materials during the Covid-19 Pandemic
}

\author{
Khairunnisa Maharani, Saiyidah Mahtari, *Suyidno \\ Physics Education Department, Faculty of Teacher Training and Education, Universitas \\ Lambung Mangkurat, Banjarmasin, Indonesia
}

*Corresponding Author e-mail: suyidno_pfis@ulm.ac.id

Received: November 2021; Revised: November 2021; Published: December 2021

\begin{abstract}
Scientific creativity and scientific attitude play an important role in learning physics, but both of those competencies are not properly trained. Therefore, the purpose of this study is to describe the effectiveness in increasing scientific creativity and students' scientific attitude. The research is part of a development research using the ADDIE model. In the ADD (Analysis, Design, Development) stage, a CRBL package has been produced that has met the valid and reliable criteria; so that the device can be continued at the IE (Implementation, Evaluation) stage by using a one group pre-test and post-test design. The research subjects were 22 students of class $\mathrm{X}$ in one of the senior high schools in the city of Banjarmasin. The data were obtained using instruments of scientific creativity test and scientific attitude questionnaires. The results of the study show that the n-gain of scientific creativity is 0.34 in the medium criteria, although every scientific creativity indicator has not reached the school minimum completeness criteria due to the online learning process. Also, the students' scientific attitude has increased at each meeting in good criteria. Thus, CRBL is effective in increasing scientific creativity and students' scientific attitudes during the COVID-19 pandemic.
\end{abstract}

Keywords: Creative responsibility based learning; scientific attitudes; scientific creativity

How to Cite: Maharani, K., Mahtari, S., \& Suyidno, S. (2021). Improving Scientific Creativity and Scientific Attitude of Students through Creative Responsibility Based Learning on Energy-Work Materials during the Covid-19 Pandemic. Prisma Sains : Jurnal Pengkajian Ilmu dan Pembelajaran Matematika dan IPA IKIP Mataram, 9(2), 325-335. doi:https://doi.org/10.33394/j-ps.v9i2.4386

https://doi.org/10.33394/j-ps.v9i2.4386

Copyright $\odot$ 2021, Maharani et al This is an open-access article under the CC-BY License. (c) (i)

\section{INTRODUCTION}

The rapid development of science and technology in the future for education world that not only stressing the intellectual, but creativity scholarly and scientific attitude should also be developed (Suyidno \& Nur, 2015). It acts central to the competence of the individual being able to compete in the future now. Therefore, the current world of education is required to be able to produce human resources who are able to think at a high level, namely having the ability to reason logically, systematically, critically, carefully, and creatively in solving problems. It is necessary to confront the time progress a dynamic, developing, and more advanced (Mardhiyana \& Sejati, 2016). Education is currently directed at improving the quality of education to produce graduates who are creative and innovative in dealing with various real-life problems. It is supported by Stenberg (in Suyidno \& Nur, 2015) That the modern world need scientific creativity in order to face all the problems in this world. Some ability that should be owned students are able to put themselves properly, to solve the problems faced by, in daily life and capable of producing creative ideas to face and compete in the intense global competition. 
The development of scientific creativity and scientific attitude gets the main attention in the 2013 curriculum. The 2013 curriculum requires science learning based on creative problem solving skills through a scientific approach. Kotimah, et al (2015) said that students are accustomed to think critically, creatively, and systematically in solving problems. The scientific approach is the basic foundation in learning natural sciences, including the field of physics. Students are expected to be able to explore their abilities through scientific process skills in order to find facts from various natural phenomena through a series of scientific processes that are built on scientific attitudes, so that they are able to produce scientific products.

The future prospect in each learning process is to improve the ability of students to be able to develop themselves and be able to solve problems creatively in life. For that reason, students must have the capacity to organize scientific attitude and learn solve problems early. Mukhopadhyay (in Putra, Lumbantoruan, \& Samosir, 2019) said that scientific attitude provides a description of students' learning attitudes when responding to problems, carrying out tasks, and developing themselves, so that they have a positive impact on student learning activities. High reasoning ability makes it easier for students to understand physics material. Therefore, learning physics needs to involve the habituation of a scientific attitude (Kusuma, Rosidin, \& Viyanti, 2013).

The development of creativity and scientific attitude of students gets the main attention in the 2013 curriculum, but in its implementation it is still not maximized. The learning process is still fixated on the conventional way and emphasizes the intellectual realm narrowly and the lack of attention to the development of students creativity, causes students scientific creativity to be hampered. According to Hamsar (2020) the main factor inhibiting the development of students scientific creativity is the teaching style in the form of the lecture method which is considered boring by students. The assumption that educators know better than students makes the lecture method still widely implemented in the learning process. Even though the rapid development of technology and communication today allows students to access information and have knowledge that was previously only owned by educators. While learning physics requires not only theoretical understanding, but also understanding in its implementation in everyday life which requires students to think creatively and the emergence of scientific attitudes in students. It's just that most of the activities of the learning and teaching process which are limited to the lecture method given by educators cause the purpose of learning to increase the creativity and scientific attitude of students has not been achieved properly. This is supported by the results of the study Trends in International Mathematic and Science Study (TIMSS) in 2011 shows that Indonesia is in the bottom 3 of the 32 participating countries. The science score owned by students in Indonesia is 406 from the specified science standard, which is 500. Similar results can also be seen from the results of the study Programme for International Student Assesment (PISA) in 2003, whose survey objects are students under 15 years old. There are three aspects that are assessed in PISA, namely the ability to read, math, and science. The results obtained by Indonesia for science or science ability are by occupying the 38th position out of 41 participating countries. In the results of international studies obtained, both TIMSS and PISA are research studies in which they provide and test students higher order thinking skills, one of which is creative thinking. Of course, the above results illustrate the need for learning by increasing creative thinking.

Teachers generally have not used methods that direct students towards creativity and scientific attitudes, especially during the current pandemic. As happened at SMAN 3 Banjarmasin, physics teachers still use methods that have not sharpened the creativity of students. This is reinforced by the observations of researchers during the Field Experience Practice program during the pandemic that occurred from September to October 2020 where teachers only gave assignments through the school site, without any explanation of the material in the learning. This has an impact on students who do not understand the physics material presented, and are not trained in creativity and scientific attitude during the learning 
process. In line with Guilford (in Munandar, 2004) that "The development of creativity is neglected in formal education (schools), even though it is very meaningful for the development of children's potential as a whole and for the advancement of science and art and culture". The problems that occur above are in accordance with the facts that occur in the field with a lot of learning using conventional models that prioritize the lecture method, text book oriented and teacher centered. So that the thinking ability of elementary level students is still relatively low because they only pay attention to the teacher.

Physics teachers must be able to present the right container or model to train students' scientific creativity and scientific attitude. One of them is by applying Creative Responsibility Based Learning (CRBL). CRBL is the development of innovative learning models to maximize the responsibility of students in supporting the success of tasks related to scientific creativity (Arifuddin, Suyidno, Nur, \& Yuanita, 2018). Suyidno et al. (2017) stated that the application of $C R B L$ effectively maximizes process skills in designing creative products. Research result by Rif'at (2020) shows that the pre-test data is 43,44 and the post-test is 65,58 which shows an increase in scientific creativity with $C R B L$. However, previous research has not measured the habituation of students scientific attitudes during learning. Therefore, in this study, researchers do not only measure scientific creativity, but also the scientific attitude of students. Scientific creativity is emphasized on indicators of scientific imagination, improving product usability technically, and designing creative products; while the scientific attitude of researchers on aspects of cooperation, responsibility, honesty, and thoroughness. The selection of these indicators takes into account the needs of students in one of the senior high schools in the city of Banjarmasin who need a stimulus to create creativity and scientific attitudes in the midst of the existing pandemic learning. This is reinforced by the results of interviews with physics teachers obtained information that scientific attitudes have been carried out at SMAN in Banjarmasin and the impact felt by students and schools includes increasing students scientific attitudes because the teaching and learning process is not boring and does not only rely on the lecture method, so that have a positive impact on quality development at SMAN in the city of Banjarmasin.

Based on this background, this study aims to describe the effectiveness of $C R B L$ in increasing scientific creativity and students scientific attitude towards work and energy. This material was chosen based on the researcher's consideration that the material is very close to its implementation in everyday life. Through $C R B L$; students are accustomed to dealing with situations and conditions that require them to display and actualize scientific creativity and scientific attitude in the physics learning process.

The research subject is the CRBL tool for work and energy, while the object of this research is the effectiveness of the $C R B L$ model for work and energy for training students' scientific creativity and scientific attitude. This research was conducted in March 2021. The research subjects were 22 students from X PMIA SMAN 3 Banjarmasin.

\section{METHOD}

Development research using the ADDIE model at the ADD stage (Analysis, Design, Develop) this has resulted in a CRBL device with validity and reliability values for lesson planning design $(3,11 ; 0,87)$; teaching materials $(3,32 ; 0.84)$; student worksheet $(3,19 ; 0.84)$; scientific creativity assessment sheet $(3,48,0.76)$; and scientific attitude assessment sheet $(3,27 ; 0.78)$. It means that the $C R B L$ device meets the valid and reliable criteria so that after being revised according to the validator's suggestions, it can be continued on the implementation test in the classroom.

$I E$ stage (Implementation, Evaluation), the researcher tested the $C R B L$ device using a one group pre-test and post-test design: $\mathrm{O}_{1} \mathrm{X} \mathrm{O}_{2}$. The research begins by asking students to do a pre-test of scientific creativity $\left(O_{1}\right)$, in the form of essay questions to measure the ability of scientific imagination, improve product usability technically, and design creative products. 
Furthermore, the implementation of the $C R B L$ device in physics learning in the classroom for 3 meetings (X). Teacher activities in implementing $C R B L$ are presented in Table 1.

Table 1. Implementation of CRBL

\begin{tabular}{lccc}
\multicolumn{1}{c}{ Phase } & \multicolumn{3}{c}{ Meetings } \\
\cline { 2 - 4 } & $\mathbf{1}$ & $\mathbf{2}$ & $\mathbf{3}$ \\
\hline Generating creative responsibility & $\sqrt{ }$ & $\sqrt{ }$ & $\sqrt{ }$ \\
Organizing creative learning needs & $\sqrt{ }$ & $\sqrt{ }$ & $\sqrt{ }$ \\
Guiding group investigations & $\sqrt{ }$ & $\sqrt{ }$ & $\sqrt{ }$ \\
Strengthen the responsibility in showing scientific creativity & - & $\sqrt{ }$ & $\sqrt{ }$ \\
Evaluation and reflection & $\sqrt{ }$ & $\sqrt{ }$ & $\sqrt{ }$ \\
\hline
\end{tabular}

At meeting 1, the teacher motivates and builds students creative responsibilities by suggesting the benefits of objects for scientific purposes (for example: the use of balls in sports activities); organizing creative learning needs (forming 6 creative teams and then presenting student worksheets); guide group investigations (discuss to find creative solutions). However, the limited learning time caused the learning process to end, so at meeting 1 , there was no writing responsibility phase advertising material. However, it soon ends with evaluation and reflection. Meeting 2 as a continuation of meeting 1; the teacher reminds students of creative student responsibilities and creative learning needs. Students are allowed to actualize their creativity responsibilities (presentation and discussion of scientific research results), then ends with evaluation and reflection. At meeting 3, each phase was carried out in full. During the learning process, students at the end of the lesson fill out a google form in the form of a self-assessment scientific attitude questionnaire with indicators of cooperation, responsibility, honesty, and thoroughness during learning. Furthermore, this research ends by asking students to do a post-test of scientific creativity $\left(\mathrm{O}_{2}\right)$, while the posttest indicators are the same as the pre-test.

The value of scientific attitude is obtained from the number of scores obtained divided by the maximum number of scores multiplied by 100. Meanwhile, the results of the pre-test and post-test of scientific creativity by converting the data using the scoring rubric in Table 2

Table 2. Scientific creativity assessment rubric

\begin{tabular}{|c|c|c|}
\hline Indicator & Dimensions & Criteria \\
\hline $\begin{array}{l}\text { 1. Improve Product } \\
\text { Usability }\end{array}$ & Fluency & $\begin{array}{l}\text { Count all the correct responses given. Each correct } \\
\text { response scores } 1 \text {. }\end{array}$ \\
\hline \multirow{2}{*}{$\begin{array}{l}\text { Technically } \\
\text { 2. Scientific } \\
\text { Imagination }\end{array}$} & Fleksibility & Counts the number of correct approaches given. \\
\hline & Originality & $\begin{array}{l}\text { Tabulate the frequency of all correct responses } \\
\text { obtained. The frequency and percentage of each } \\
\text { response is calculated and one answer that has a } \\
\text { response probability less than } 5 \% \text { is given a score of } 2 \text {; } \\
\text { if the probability of } 5 \text { to } 10 \% \text { is given a score of } 1 \text {; if the } \\
\text { response probability is greater than } 10 \% \text { it is given a } \\
\text { score of } 0 .\end{array}$ \\
\hline \multirow{2}{*}{$\begin{array}{l}\text { 3. Creative Product } \\
\text { Design }\end{array}$} & Fleksibility & Counts the number of correct approaches given. \\
\hline & Originality & $\begin{array}{l}\text { Tabulate the frequency of all correct responses } \\
\text { obtained. The frequency and percentage of each } \\
\text { response is calculated and one answer that has a } \\
\text { response probability less than } 5 \% \text { is given a score of } 2 \text {; } \\
\text { if the probability of } 5 \text { to } 10 \% \text { is given a score of } 1 \text {; if the } \\
\text { response probability is greater than } 10 \% \text { it is given a } \\
\text { score of } 0 .\end{array}$ \\
\hline
\end{tabular}

(Hu \& Adey, 2010) 
Based on Table 2, the value of scientific creativity is obtained from the total score divided by the highest score of students in the class multiplied by 100 . The acquisition of scientific creativity and scientific attitude is adjusted to the criteria: 0-40 (low); 41-55 (not good); 56-65 (enough); 66-80 (good); 81-100 (very good) (Suyidno, Nur, Yuanitas, 2019). In addition, the increase in students scientific creativity was calculated using the $\mathrm{N}$-gain equation with the following criteria: 0.00-0.29 (low); 0.30-0.69 (medium); 0.70-1.00 (high) (Hake, 1998).

\section{RESULTS AND DISCUSSION}

The effectiveness of $C R B L$ describes the achievement of students in scientific creativity and scientific attitude after the implementation of $C R B L$. The achievements of scientific creativity and scientific attitude of students will be presented below.

\section{Scientific Creativity of Students}

Scientific creativity data was obtained from the results of the pre-test and post-test of students. The achievements of students scientific creativity after applying CRBL are presented in Table 3.

Table 3. Indicator value pre-test, post-test, and n-gain scientific creativity

\begin{tabular}{|c|c|c|c|c|c|c|}
\hline \multirow{2}{*}{ Indicator } & \multicolumn{2}{|c|}{ Pre-test } & \multicolumn{2}{|c|}{ Post-test } & \multicolumn{2}{|c|}{$N$-Gain } \\
\hline & Score & Criteria & Score & Criteria & $\mathbf{g}$ & Criteria \\
\hline Scientific Creativity & 46.97 & Not good & 57.85 & Enough & 0.21 & Low \\
\hline $\begin{array}{l}\text { Improving Product } \\
\text { Usability Technically }\end{array}$ & 27.27 & Not good & 65.45 & Good & 0.52 & Medium \\
\hline $\begin{array}{l}\text { Designing Creative } \\
\text { Products }\end{array}$ & 34.09 & Not good & 66.48 & Good & 0.49 & Medium \\
\hline
\end{tabular}

Based on Table 3; it turns out that the scientific creativity of students at first was still low. Based on information from the answers during the pre-test on indicators of scientific imagination, students were asked to write down what would happen if all vehicles in Indonesia used cars and electric motorcycles which are known to be environmentally friendly. Initially out of 22 students, there were 2 people who did not answer, 20 people who were able to provide answers. Based on the answers obtained information there are several variations of answers and approaches by students. The answers with the greatest frequency include: no air pollution with an environmental approach and saving fuel use with an economic approach. While the smallest frequency, namely: reducing carbon emissions with an environmental approach. Although most students have written answers, but in Table 3, the average score of scientific imagination in the criteria is not good because students provide few answers (related to fluency scores), approaches that do not vary (related to flexibility), and between participants students have the same answer (related to originality).

Otherwise; post-test data showed participants scientific creativity was better than before $C R B L$ was applied. All students can provide more variety of answers than the pre-test. The learning process with $C R B L$ affects the transfer of knowledge so that students answers are more diverse. This is in line with Piaget (in Suciati \& Irawan, 2001) that the learning process that is held must be in line with the stages of cognitive development of students, which include assimilation, accommodation and equilibration (balancing). The assimilation stage is aimed at unifying (integrating) new information into a previously existing cognitive structure. The accommodation stage aims to adjust the cognitive structure to the new situation. The equilibration stage is intended to adjust the continuity between assimilation and accommodation. There are many answers with low frequency and varying approaches. Students who give answers with a small frequency are able to think out of the ordinary. 
However, the class average score for scientific imagination is still in quite good criteria and is below the minimum completeness criteria. According to Ahmadi \& Supriyono (in Cahyono, 2019); internal factors and external factors are the two main factors causing learning difficulties. Internal factors are physiological factors (physical conditions) and psychological factors (psychological conditions). While external factors are family, school, and community factors. Factors that cause it include, there is still an imbalance between the number of answers with the highest number of students which affect the fluency score and the discovery of students who have alternative original answers with large frequencies so that the original score is 0 . However, the process creative learning has been able to have an influence on the imagination of students as evidenced by the increase in the scientific imagination score as shown in Table 3.

On the indicator of improving product usability technically, students are asked to find solutions in the form of what will be done to make lamps more efficient and different from other products, for example students will build the largest light bulb company in Borneo. During the pre-test of 22 students, only 6 students were able to answer. Students who can provide answers tend to have the same answer, which is seen in the greatest frequency, namely in the aesthetic approach with bulb answers in various shapes.

After the post-test was conducted, the students were able to provide different alternative answers, for example from a technological approach, namely: emergency lamp, eye comfort, LED lamp, solar power, and technology so as not to cause excessive heat; then from the economic approach, namely affordable prices; then from the aesthetic approach, namely the bulb with a variety of unique shapes and motifs typical of the region; up to the answer to make lamps like spare parts if they are damaged, by only replacing the damaged components. After calculating the score with the indicator of improving the technical usability of the product, the average score of the pre-test class was 27.27 with the bad category increasing to 65.45 with the good category after the post-test but still below the minimum completeness criteria. The factor that causes it is that there are still many students who are unable to answer but the creative learning process has been able to have an influence on the imagination of students as evidenced by an increase in the score for solving creative problems.

In the indicator of designing creative products, students are asked to design products that make it easier for fruit farmers when the harvest season arrives. At the time of the pretest of 22 students, there were 18 people who could answer and 4 people who didn't answer anything. The 18 students who could answer this mostly only answered in the form of text without accompanied by pictures, so it can be concluded that there are still many students who are constrained by this third indicator. This was reinforced at the second meeting, when students were asked about the third indicator, namely designing creative products, there were still many who were unskilled in drawing, did not have the courage, and did not understand what to draw.

After the post-test, all students can provide answers. The most widely used design is a small truck that has a fruit holder and wheels under it, but some students are able to provide additional tools in certain parts to make it more useful. Of the many answers, there is a unique answer, namely the design of a fruit robot with robotic hands like a net with bluetooth that helps fruit farmers when harvesting. After calculating the score for designing creative products from the average pre-test score of 34.09 with bad criteria, after the post-test the score becomes 66.48 with good criteria. A significant increase in this indicator is because students are directly involved in the experience of designing and drawing on the concepts of the material they are learning. This is in line with the results of research by Muhammad Asdam (in Fitrian, 2012) which shows that image media is very effective in improving learning outcomes. Although the ability of students to design products creatively is under the minimum completeness criteria, the creative learning process has been able to have an influence on students as evidenced by the increase in scores for designing products creatively. 
The increase in scientific creativity above is reinforced by the results of the analysis of the mean pre-test, post-test, and n-gain of scientific creativity in Table 4.

Table 4. The mean value of pre-test, post-test, and N-gain of scientific creativity

\begin{tabular}{cccc}
\hline Pre-test & Post-test & N-gain & Criteria \\
\hline 54.17 & 69.84 & 0.34 & Medium \\
\hline
\end{tabular}

Based on Table 4; at first, students had difficulty in answering essay questions, in the end, students got used to answering and analyzing the questions that had been provided. The average score of scientific creativity is still below the minimum completeness criteria, but an increase in the score of scientific creativity is supported by the $\mathrm{N}$-gain value (Table 4) that the increase in students scientific creativity is in the medium category. Means, the application of $C R B L$ can increase the scientific creativity of students in the medium criteria. Students are able to apply their knowledge to work on scientific creativity questions well. This is supported by the results of research by Yanti, Miriam, \& Suyidno (2020) that educators facilitate, organize creative needs, encourage the process of scientific investigation and actualization of creative responsibilities, as well as good evaluation and reflection. Thus, $C R B L$ can maximize scientific process skills in designing students' creative design products (Suyidno et al., 2017).

\section{Scientific Attitude of Students}

The effectiveness of learning is also seen from the scientific attitude of students. The scientific attitude data of students is carried out using a scientific attitude questionnaire in the form of self-assessment at each meeting. In line with Wijayanti (2017) that self-assessment is an assessment method that provides opportunities for students to take responsibility for their own learning. Students are good judges of their own feelings and assignments. Therefore, the self-assessment process can be carried out by the teacher by asking for validation from the thoughts of students. The results of the scientific attitude analysis are presented in Figure 1.

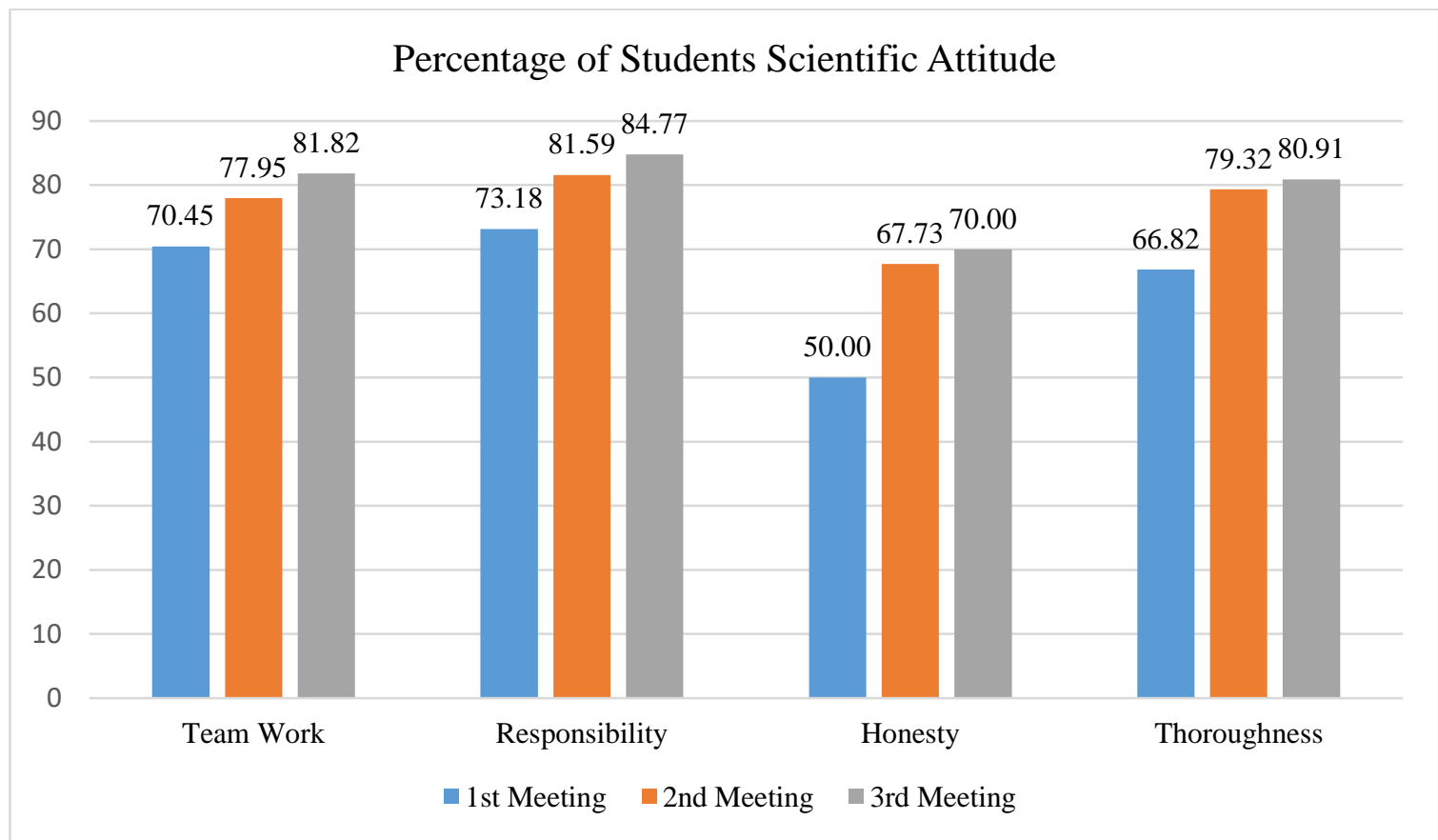

Figure 1. The percentage of students scientific attitudes at meetings 1, 2, and 3

Figure 1 shows that the scientific attitude of students has increased at each meeting. The scientific attitude questionnaire includes indicators of cooperation, responsibility, honesty, and thoroughness. Scientific attitude questionnaires are always filled out at each meeting at the end of the lesson. The results of the effectiveness of the scientific attitude questionnaire can be seen in Figure 1, where there is an increase in each meeting. The 
effectiveness of self-assessment is also conveyed by Willey \& Gardner (2010) reflected in the positive influence that has an impact on learning outcomes, such as an increase in learning outcomes and learning motivation, students can also get constructive feedback from a group of friends.

At the first meeting, students were just involved in teaching and learning activities using the CRBL model. During group discussions, students are able to work together in teams, it's just that there are still many students who do not participate in working on the student worksheet that has been provided. It can be seen that only a few teams collect student worksheet assignments through the provided google form. Then at the time of the presentation, it was seen that the responsibility of the students was in conveying the answers they had previously prepared with the discussion team, but there were some students who were not ready with the student worksheet answers that their team had due to lack of participation. In terms of honesty and thoroughness, students seemed to answer honestly on the student worksheet that had been provided and with good responses from other teams when correcting or checking the answers of other discussion teammates. So, as an evaluation for the second meeting. Teachers must find ways to increase student participation, in this case teachers must provide more stimulus so that students are able to participate in classroom learning. This is supported by Mahendra, Bayles, Tomoeda, \& Kim (2005) that in planning class activities, focus on identifying the needs of students. For example, students engage in dialogue that challenges beliefs and creates conceptual change. Learning-centred is a very effective approach to problems, because students can benefit from a variety of present perspectives. This approach transforms the classroom from a teacher center to a learner center.

At the second meeting, the teacher had overcome the problems at the first meeting, especially the problem of cooperation and responsibility by asking passive students as representatives in presenting the results of their group discussions. This method is effective, so that there is no gap between active and passive students. In this case the teacher uses student-centered so that students can be active in presenting their presentations. In line with Weimer (in Wright, 2011) making conclusions in learning that placing students as the main subject of learning can change the teacher's role from "a person who controls on stage" to "a mentor on the side" who views students not as empty containers that must be followed, filled with knowledge but as seekers to be guided together in the journey of intellectual development.

At the third meeting, the scientific attitude of the students from the four indicators was very prominent. This can be seen from some students who began to venture to present the answers of the discussion team without any coercion. As well as the participation of students who are usually passive, at the third meeting, students were seen who were enthusiastic in providing feedback and responses to other students who presented their answers. And it can also be seen from some of the attitudes of students who are careful with the answers of discussion friends from other teams. In line with Wood (2003) that group learning not only facilitates students to gain knowledge, but also other skills such as communication skills, cooperation, problem solving, independence, responsibility for learning, sharing information, and respecting others. So that from the first meeting to the third after the $C R B L$ model was applied, students were trained and accustomed to working together, responsibility, honesty, and thoroughness.

There was an increase in each meeting of the scientific attitude of students. Students follow all directions of activities/tasks delivered by the teacher. Learners also demonstrate the social skills needed to work effectively with others to complete common tasks. Students have shown a responsible attitude by answering individual and group questions and are responsible when presentations are made. Students are able to answer honestly the questions that have been given both individually and in groups. Students are able to be thorough on individual 
questions, group questions and provide feedback to other discussion teams so that the tasks they do can finally be done effectively.

The implementation of $C R B L$ is able to increase the scientific creativity and scientific attitude of students, but the increase in each indicator of scientific creativity has not yet reached the school minimum completeness criteria. The lack of achievement of the minimum completeness criteria for scientific creativity is influenced by various factors, including the Covid-19 pandemic. The Covid-19 pandemic has brought about various changes in all sectors, including the education sector in Indonesia. One of the government's efforts to overcome this problem is by issuing a Circular Letter of the Minister of Education and Culture No. 3 of 2020 concerning Prevention of Covid-19 in Education Units, and Number 36962/MPK.A/HK/2020 concerning online learning and working from home.

This policy encourages education observers to design various distance learning methods so that the learning process can continue. Distance learning method allows the learning process to take place without face to face or online (Ramanta \& Widayanti, 2020). In the results obtained at the time of research on scientific creativity through pre-test and posttest, it was found that the $N$-gain was 0.34 in the medium category, but each indicator had an increase in its assessment even though it was still below the minimum completeness criteria. The same applies to the scientific attitude questionnaire, which increases in each meeting.

In online learning at SMAN 3 Banjarmasin, researchers used zoom meeting and whatsapp as media to support the provision of knowledge transfer, teaching and also learning process with students. In using zoom meetings, there are still many students who do not follow the lesson either from bad connections, quotas, or other factors. This is supported by research by Ramanta \& Widayanti (2020) that obstacles in using zoom meetings during the learning process include poor internet connections, wasteful use of internet quotas, and requiring additional efforts for teachers to explain learning materials. As well as research by that when online the provision of material is less effective because when viewed from basic competencies some are not fulfilled, so the learning process is not optimal.

In fact, in the learning process of natural sciences, especially physics, a good transfer of knowledge must be carried out so that there are no misconceptions. In line with Resmawati, Prabowo, \& Munasir (2018) that learning natural sciences can be more meaningful if it is done through discovery, experimentation or direct experience of students. This will help students to more easily understand natural phenomena. Through direct experience, students are also able to store the knowledge they have in long-term memory. As contained in natural science lessons in the 2013 curriculum which emphasizes the learning process through a scientific approach, including observing, asking, trying, reasoning, and communicating. Some of the factors above are the reasons why the achievement of scientific creativity has not reached the minimum school completeness criteria. In the future, teachers must maximize the transfer of knowledge so that the learning and teaching process is maximized and the goals to be achieved can be carried out properly. Good learning management is also needed from both online and offline learning. So that in the process, teachers become more creative and innovative in classroom management.

\section{CONCLUSION}

The implementation of $C R B L$ is able to increase the scientific creativity and scientific attitude of students, although the achievement of each indicator of scientific creativity has not reached the minimum completeness criteria. Even during the Covid-19 pandemic; scientific creativity and scientific attitude must still receive important attention in physics learning.

\section{RECOMMENDATION}

The next research recommendation is the need for $C R B L$ trials on a wide scale to measure the achievements of scientific creativity and scientific attitudes during the Covid-19 pandemic. 


\section{ACKNOWLEDGMENT}

The study did not receive any special grants from any funding agency in the public, commercial, or nonprofit sectors.

\section{REFERENCES}

Arifuddin, M., Suyidno, Nur, M., \& Yuanita, L. (2018). Menggali Potensi Kreativitas Ilmiah Mahasiswa melalui Model Creative Responsibility Based Learning. Seminar Nasional Pendidikan Banjarmasin.

Cahyono, H. (2019). Faktor-Faktor Kesulitan Belajar Siswa MIN Janti. Jurnal Dimensi Pendidikan dan Pembelajaran, 7(1), 1-4.

Effendy, I. (2016). Pengaruh Pemberian Pre-test dan Post-test Terhadap Hasil Belajar Mata Diklat HDW.DEV.100.2.A pada Siswa SMK Negeri 2 Lubuk Basung. VOLT: Jurnal Ilmiah Pendidikan Teknik Elektro, 1(2), 81-88.

Hake, R. R. (1998). Interactive-Engagement Vs Traditional Methods: A Six-Thousand Student Survey of Mechanics Test Data for Introductory Physics Courses. American Journal of Physics, 66(1), 66-74.

Hamsar, I. (2020). Penerapan Model Pembelajaran Project Based Learning Berbasis Sendratasik pada Mata Pelajaran Seni Budaya untuk Meningkatkan Kreativitas dan Aktivitas Belajar Peserta Didik di SMA Negeri 4 Takalar. Makassar: Universitas Negeri Makassar.

Hu, W., \& Adey, P. (2010). A scientific creativity test for secondary school students. International Journal of Science Education, 24(4), 389-403.

Kotimah, E. K., Rosidin, U., \& Wahyudi, I. (2015). Pengembangan Instrumen Assessment Sikap Ilmiah dan Keterampilan Proses Sains dengan Scientific Approach. Jurnal Pembelajaran Fisika, 3(3).

Kusuma, M. D., Rosidin, U., \& Viyanti. (2013). Pengaruh Sikap Ilmiah terhadap Hasil Belajar dan Kemandirian Belajar melalui Strategi Scaffolding-Kooperatif. Jurnal Pembelajaran Fisika 1, 2.

Mahendra, N., Bayles, K. A., Tomoeda, C. K., \& Kim, E. S. (2005). Diversity and LearnerCentered Education. The ASHA Leader, 10(16), 12-19.

Mardhiyana, D., \& Sejati, E. O. (2016). Mengembangkan Kemampuan Berpikir Kreatif dan Rasa Ingin Tahu Melalui Model Pembelajaran Berbasis Masalah. PRISMA, Prosiding Seminar Nasional Matematika, (pp. 672-688).

Munandar, U. (2011). Pengembangan Kreativitas Anak Berbakat. Jakarta: Rineka Cipta.

Purwanto. (2019). Analisis Korelasi dan Regresi Linier dengan SPSS 21 (Panduan Praktis untuk Penelitian Ekonomi Syariah). Magelang: Staia Press.

Putra, D. S., Lumbantoruan, A., \& Samosir, S. C. (2019). Deskripsi Sikap Siswa: Adopsi Sikap Ilmiah, Ketertarikan Memperbanyak Waktu Belajar Fisika dan Ketertarikan Berkarir di Bidang Fisika. Tarbiyah: Jurnal Ilmiah Kependidikan, 8(2), 91-100.

Ramanta, D., \& Widayanti, F. D. (2020). Pembelajaran Daring di Sekolah Menengah Kejuruan Putra Indonesia Malang pada Masa Pandemi Covid 19. Seminar Bimbingan dan Konseling (pp. 61-67). Malang: Universitas Wisnudhana Malang.

Raupu, S. (2017). Analisis Hasil Belajar Integral dengan Menggunakan Soal Pilihan Ganda dan Soal Essay (Studi Perbandingan pada Mahasiswa Semester II Prodi Tadris Matematika IAIN Palopo). Pedagogy: Jurnal Pendidikan Matematika, 2(2), 47-58.

Resmawati, F. S., Prabowo, \& Munasir. (2018). The Discovery Learning Model with A Scientific Approach to Increase Science Learning Achievement of Students. 
Mathematics, Informatics, Science, and Education International Conference (MISEIC 2018). 157, pp. 198-200. Surabaya: Atlantis Press.

Rif'at, M. F., Wati, M., \& Suyidno. (2020). Developing Students' Responsibility and Scientific Creativity through Creative Responsibility Based Learning in Learning Physics. Berkala Ilmiah Pendidikan Fisika, 8(1), 12-22.

Suciati, \& Irawan, P. (2001). Teori Belajar dan Motivasi. Jakarta: PAU-PPAI, Universitas Terbuka.

Suyidno, \& Nur, M. (2015). Pemahaman Kreativitas Ilmiah Mahasiwa dalam Pembelajaran Kreatif pada Mata Kuliah Fisika Dasar. Seminar Nasional Pendidikan Sains 2015 (pp. 1361-1366). Surabaya: Universitas Negeri Surabaya.

Suyidno, Dewantara, D., Nur, M., \& Yuanita, L. (2017). Maximizing Students' Scientific Process Skill within Creative Product Design : Creative Responsibility Based Learning. 5th SEA-DR (South East Asia Development Research) International Conference 2017 (SEADRIC 2017) (p. 1). Atlantis Press.

Suyidno, Nur, M., \& Yuanita , L. (2019). Creative Responsibility Based Learning : Kreatif Pendidiknya, Dahsyat Peserta Didiknya. Banjarmasin: Universitas Lambung Mangkurat Press.

Suyidno, Nur, M., Yuanita, L., \& M, A. S. (2019). Creative Responsibility Based Learning : Kreatif Pendidiknya, Dahsyat Peserta Didiknya. Banjarmasin: Lambung Mangkurat University Press.

TIMSS and PIRLS International Study Center. (2011).

Wijayanti, A. (2017). Efektivitas Self Assessment dan Peer Assessment dalam Pembentukan Karakter Siswa. Realta: Jurnal Penelitian dan Kebudayaan Islam, 15(2).

Willey, K., \& Gardner, A. (2010). Investigating The Capacity of Self-Assessment and PeerAssement to Engange Student and Increase Their Desire to Learn. European Journal of Engineering Education, 35(4), 429-443.

Wood, D. F. (2003). ABC of Learning and Teaching in Medicine. Problem Based Medicine. BMJ, 326, 328-330.

Wright, G. B. (2011). Student-Centered Learning in Higher Education. International Journal of Teaching and Learning in Higher Education, 23(1), 92-97.

Yanti, L., Miriam, S., \& Suyidno. (2020). Mengembangkan Keterampilan Proses Sains Peserta Didik Melalui Creative Responsibility Based Learning. JPPS (Jurnal Pendidikan Sains), 9(2), 1790-1796. 